\title{
Navigating disciplinary challenges to global sustainability science: an archaeological model
}

\author{
Mark J. Hudson \\ Research Institute for Sustainable Environments and Cultures, University of West Kyushu, \\ Kanzaki, Saga Prefecture, JP \\ hudsonm@nisikyu-u.ac.jp
}

\begin{abstract}
Current threats posed by anthropogenic climate change, biodiversity loss, the degradation of ecosystem services, and other related impacts of human activity require a concerted response through a global science of sustainability. The threats faced by humanity are so extensive that all academic disciplines are affected in some way and all have a role to play in developing potential responses. Given that few academic disciplines have traditionally focused on issues of ecology or sustainability, however, major challenges remain with respect to how we might build a global science of sustainability that can support concrete policy and interventions. This paper proposes a developmental model with five levels of research and practice required for an effective global sustainability science and examines some of the challenges faced by archaeology in moving up these levels.

IZVLEČEK - Trenutne nevarnosti, ki jih povzročajo človeško pogojene klimatske spremembe, izguba biodiverzitete, degradacija ekosistemov in drugi sorodni vplivi človeške dejavnosti, potrebujejo poglobljen odgovor preko svetovne teorije vzdržljivosti. Nevarnosti, s katerimi se sooča človeštvo, so tako obsežne, da vplivajo na vsa akademska področja enako, zato bi morali vsi sodelovati pri iskanju rešitev. Kako zgraditi svetovno znanost o vzdržljivosti, ki bi podpirala konkretne strategije in intervencije, pa ostaja velik izziv, saj se le redke akademske discipline tradicionalno ukvarjajo z vprašanji o ekologiji ali vzdržljivosti. V članku predlagam razvojni model s petimi nivoji raziskovanja in praks, ki so potrebne za učinkovito svetovno znanost o vzdržljivosti, in ki preučujejo nekatere izzive, s katerimi se sooča arheologija, ko se pomika po teh nivojih.
\end{abstract}

KEY WORDS - sustainability; interdisciplinarity; archaeological research

\section{Introduction}

Current threats posed by anthropogenic climate change, loss of biodiversity and wilderness, the degradation of ecosystem services, hyper-consumption of consumer goods and resources, the accumulation of chemical, biological and nuclear wastes, and other related impacts of human activity require a concerted response through a global science of sustainability (Chapin et al. 2009). The global condition of the $21^{\text {st }}$ century will be defined by the disruptions resulting from these problems (Menely 2012.478). The threats faced by humanity are so great that all academic disciplines are affected in some way and all have a role to play in developing potential re- sponses. Given that few academic disciplines have traditionally focused on issues of ecology or sustainability, however, major challenges remain with respect to how we might build a global science of sustainability that can support concrete policy and interventions. There seems to be almost universal agreement that our current crisis requires greater interdisciplinarity and that sustainability science is, by definition, a highly interdisciplinary endeavor (Clark, Dickson 2003). While, however, there have been numerous calls for such an interdisciplinarity (Chapin et al. 2011; Nisbet et al. 2010), few studies have examined the implications for particular dis- 
ciplines. Academic disciplines and scientific knowledge will not by themselves be enough to bring about the required social changes for a truly sustainable world. Nevertheless, there is a need to consider trajectories toward sustainability both within the academy in general and within specific disciplines.

Our present condition requires a completely new type of science in order to enhance human wellbeing and the resilience of social-ecological systems (Chapin et al. 2011). That science must be able to analyse complex networks of interactions between humans and the non-human environment across an increasingly globalised world. Research on the psychology of how people perceive and react to problems must be incorporated in order to involve a broad range of stakeholders. Finally, the 'science' must be proactive enough to actively shape trajectories of social change. Thus, the basic problem of sustainability is: "How can society transform a trajectory of environmental degradation and disparity in human well-being to a more sustainable trajectory that provides greater opportunity for present and future generations to meet their needs?" (Chapin et al. 2011.40). This agenda means that academic disciplines are not necessarily central to the ultimate aims of sustainability science; what is required is an interdisciplinary pooling of knowledge and the establishment of common frameworks and meanings (Bohm 1996; Ostrom 2009; Pickett et al. 1999). However, any interdisciplinary project first requires its constituent disciplines to engage with the issues concerned. Furthermore, assumptions that certain disciplines are or are not concerned with questions of sustainability and the environment need to be deconstructed in terms of the history of each discipline.

This paper examines archaeology as a case study in building sustainability science. Archaeology is already very multidisciplinary in the sense that it incorporates various research fields to further its aims of understanding the past. This paper considers how archaeology might also contribute to inter- and transdisciplinary approaches that could develop responses to the global ecological crisis currently faced by humankind. The paper proposes a simple developmental model with five levels of research and practice required for an effective global sustainability science, and examines some of the challenges faced by archaeology in moving up these levels. Although the present paper focuses on the possible use and implications of this model for archaeology, the model itself is designed to encompass all disciplines.

\section{Summary of the model}

The model proposed here has five levels (Fig. 1). Level 1 comprises basic research in each discipline. Some disciplines, such as ecology and geography, already include a major focus on human-environment interactions. In other fields, including archaeology, this focus may be present, but more contested. Still other disciplines may define themselves as having little or nothing to do with the natural environment, although closer consideration usually shows that this distance is spurious. Whatever the importance assigned to research on human-environment interactions within each discipline, however, it cannot be assumed that those disciplines will automatically concern themselves with issues of sustainability (Level 2). One example here is a traditional agricultural system in East Asia wherein fish are raised in wet rice paddy fields. This ancient system has long been discussed within archaeology in terms of culture history. Recent ecological research has examined the sustainability of this agricultural heritage (Xie et al. 2011), but unless archaeologists are specifically interested in issues of sustainability, it is unlikely that they will read such literature or develop further analyses related to sustainability. The integration of basic research with questions of sustainability is by no means assured.

In recent years, Level 2 type research has begun to appear in many disciplines where it was previously not present, yet the mainstreaming of such concerns is usually slow. Ecocriticism - the study of ecological and environmentalist issues within literary criticism - is one example where the shift from Level 1 to 2 occurred rather quickly in the 1990s (Buell et al. 2011). Heise (2006.506) has emphasised the "diversity of political and cross-disciplinary influences" that went into the making of ecocriticism. Such a disciplinary shift to considering sustainability issues requires major transformations in disciplinary goals and perhaps also in power structures. Pathways to this Level 2 transition probably vary significantly, depending on the discipline concerned.

While Levels 1 and 2 are primarily confined to disciplinary research, Levels 3 and 4 require broader syntheses that integrate different disciplinary knowledge. Level 3 comprises theoretical modelling of how humans interact with natural environments and also how they develop sustainability. Anthropology has a long history of research on relations between humans and nature (Crumley 2001), but has only recently begun to extend this to explicit modelling 
of sustainability (Redman 2005; Hardesty 2007; Fisher et al. 2009). Level 4 recommendations for solutions/policy are crucial to transform academic research into practical ideas for change. Level 4 requires the implementation of transdisciplinarity, meaning approaches "that move beyond the university to engage members of society" (Frodeman 2011.106). All disciplines can develop Level 3 type models, but not all disciplines regularly develop policy recommendations beyond their immediate areas of concern (for example, heritage preservation in the case of archaeology). Level 4 of the present model includes both proposed trajectories of change and suggestions about how to instigate those changes. As discussed in more detail below, the term 'policy' in Level 4 should be understood in a broad sense.

If the world is to become more sustainable, academic knowledge about sustainability has to be implemented in concrete interventions that comprise Level 5 of the model proposed here. Few disciplines regularly engage in direct interventions with communities or individuals and those with the relevant expertise - such as social work, community development and occupational therapy - are sometimes stigmatised as being less academic than more 'theoretical' disciplines. It is not suggested that all disciplines must eventually develop Level 5 interventions; such work will be best performed by those fields with the relevant experience, especially in terms of the evaluation of interventions. Archaeology, like many other disciplines, does, however, have great potential for participating in multidisciplinary interventions such as those increasingly used with indigenous peoples (e.g., Frank et al. 2008). Furthermore, 'interventions' must be understood in terms of each discipline's culture and goals, and might include museum displays, art exhibitions and poetry readings, as well as more traditional activities in sustainable community development.

Finally, while not shown in the model, there is a crucial role for the humanities in developing critical discourses about how the knowledge summarised in Figure 1 is obtained and utilised. This role should include basic critiques, including the problem of what we actually mean by 'sustainability' (cf. Alaimo 2012).

\section{Archaeological implications of the model}

Having briefly summarised the outlines of the model, this section will examine how it might be employed within archaeology.

\section{Levels 1-2: basic research and environmen- talism}

Beginning with $19^{\text {th }}$ century work on shell middens and lakeshore sites, research on the natural environment has always played an important role in archaeology (e.g., Kristiansen 2002; Habu et al. 2011). This research has always been very multidisciplinary and Solli (2011.49) argues that C. P. Snow's 'two cultures' have been "embedded in archaeology since the birth of the discipline." Historical explanations linking culture change and the environment have been common since the early $20^{\text {th }}$ century (e.g., Bruun 1918; Childe 1928). Since World War Two, basic archaeological research on the environment has been transformed by new techniques of paleoenvironmental reconstruction and by the new science of ecology (Hassan 2004). Today, research in environmental archaeology uses a wide range of extremely sophisticated methods.

Despite these technical advances, the role of the natural environment within archaeological theory has often been contested and post-processual archaeology, in particular, has downplayed environmental factors (Solli 2011; Hudson et al. 2012a). This tension over the role of nature is by no means unique to archaeology, and Oestigaard (2011.70) argues that since Durkheim "there has been a dictum in social and human sciences that social facts can be 
explained only by other social facts" and not by nature and the physical world. It is perhaps for this reason that it is only quite recently that some archaeologists have begun to consider issues of sustainability.

The type of research included here in level 2 might be best summarised as 'environmentalist', i.e., research that shows a social and ethical concern for the state of the natural environment and for human well-being within that environment. Such concerns appear to have developed more or less independently in many archaeological traditions in the 1990s, including the United Kingdom (Macinnes, Wickham-Jones 1992), Europe (van der Leeuw 1998), the United States (Redman 1999), and Japan (Yasuda 1999). Nowhere has such research become a recognisable sub-discipline within archaeology along the lines of indigenous or feminist archaeology. There is, however, a growing body of recent work corresponding to Level 2 which suggests that archaeology may have reached some sort of 'tipping point' and research in this area will become increasingly mainstream in the near future. It could also be argued that global environmental problems have become so omnipresent that it is no longer possible to read 'basic research' in environmental archaeology without also considering the implications for sustainability; a good example is a recent paper on rapid climate change in prehistory by Clare and Weninger (2010).

\section{Level 3: synthetic models in archaeology}

Historical ecology and resilience theory are two examples of the Level 3 type human-environment synthetic models that are used in archaeology. Historical ecology is an interdisciplinary approach that places human history within an ecological framework. Within archaeology, historical ecology has developed research that looks at human-landscape interactions over the long term, often across regional scales (e.g., Crumley, Marquardt 1987; Balée, Erickson 2006). Although historical ecology is not a formal explanatory theory (Crumley 2013), its broad interdisciplinary perspective has contributed to extensions into sustainability science, particularly through the 'Integrated History of the People of Earth' (IHOPE) network (Costanza et al. 2007).

Resilience theory differs from historical ecology in being a more explicit theory of socio-ecological change. Resilience theory is also a rare example of a paradigm that has grown to incorporate all five of the levels proposed here in Figure 1: basic research in boreal forest ecology (Holling 1973) was extended to social-ecological systems (Berkes, Folke 1998; Folke et al. 1998), and then to broad theoretical models of sustainability that include policy recommendations (Gunderson, Holling 2002) and some interventions (Walker, Salt 2006). The long-term time perspective of archaeology is crucial to resilience theory (Redman 2005). So far, only a few archaeologists have attempted to develop formal archaeological analyses using resilience theory (e.g., Redman et al. 2009; Butzer 2012; Dunning et al. 2012; Endfield 2012; Rosen, Rivera-Collazo 2012; Hudson et al. 2012b), but there is a growing interest in the broader issues of resilience and vulnerability within archaeology (e.g., McAnany, Yoffee 2010; Cooper, Sheets 2012). Although further research is needed on methods of measuring resilience in the archaeological record, archaeological applications of resilience theory are important for sustainability science since they identify factors that promote or reduce resilience in particular contexts, thus enabling the discipline to move up to the next level of solutions and policy.

\section{Level 4: archaeological research and envi- ronmental solutions}

Although archaeology and other historical sciences have a long tradition of Jeremiadic warnings of social collapse, only quite recently has serious interest been shown in how past societies managed for sustainability in order to avoid collapse. Any programme aimed at fostering sustainability clearly needs to develop suggestions about what needs to be done. Such suggestions can be broadly described as 'solutions' which are instigated through 'policy', but these terms need further explanation in the context of archaeology. Like many other disciplines, archaeology has not traditionally taken a direct role in formulating policy on the management of natural resources, although there are some exceptions, including work on applied zooarchaeology (Lyman, Cannon 2004). In order to consider what archaeology might contribute to sustainability policy, we first need to examine what such 'policy' might entail.

Sustainability solutions are not simply polices and regulations enforced by governments, but collaborative frameworks aimed at "social-ecological governance", defined as the "Collective coordination of efforts to define and achieve societal goals related to human-environment interactions" (Chapin et al. 2009. 351; Young et al. 2008). A range of collaborative social mechanisms are required to link institutions with social-ecological systems and adap- 
tive learning (Kofinas 2009). These mechanisms include fostering innovation and diversity, promoting social capital and social memory, valuing ecosystem services, supporting community belonging and a sense of place, paying greater attention to slow dynamics of change, and planning for surprises (Folke et al. 2003, 2009; Walker, Salt 2006; Kofinas 2009; Adger et al. 2011). Archaeology has much to contribute here in terms of public engagement in community and conservation, fostering a sense of place, promoting social capital through heritage, and increasing our understanding of the long-term dynamics of social-ecological systems. However, it is as yet unclear quite how such contributions might be implemented. The use of public archaeology in environmental education is one obvious approach, but little such work has so far been conducted (Hudson et al. 2012a).

\section{Level 5: archaeology and interventions}

Although it has been suggested that archaeology has great potential to contribute to social-ecological governance for sustainability, this will be an unfamiliar and perhaps uncomfortable role for many archaeologists. Some archaeologists - and no doubt many other scholars in the humanities - may regard policy prescriptions and social interventions as not academic or even utopian. To some extent, such thinking reflects the failure of the academy to reach the public through universities and other institutions where "The transmission of knowledge to society [is] understood as largely automatic in nature, and commonly devalued as 'dissemination', 'outreach' and 'dumbing down"' (Frodeman 2011. 107). In order to build a science of sustainability we certainly need to become better at communicating our research results. Yet this paper makes no claim that all disciplines must develop policy and interventions in the same way. Recent research in sustainability science stresses the need for multidisciplinary collaborations through which the public is "(1) empowered to learn about both the scientific and social dimensions of climate change, (2) inspired to take personal responsibility, (3) able to constructively deliberate and meaningfully participate, and (4) emotionally and creatively engaged in personal change and collective action" (Nisbet et al. 2010.329). Archaeology has the po- tential to contribute to all of these goals. Like many disciplines in the humanities and social sciences, archaeology has often adopted committed positions of social advocacy and praxis (e.g., McGuire 2008), and by their very nature such disciplinary commitments can contribute to shaping social trajectories toward sustainability.

\section{Conclusions}

This paper has proposed a model for the disciplinary development of sustainability research (Fig. 1) and discussed some applications of the model to archaeology. The discussion suggested a number of preliminary conclusions. Firstly, although the current crisis in global sustainability may tend to favour research associated with the higher levels in Figure 1 , the continuing importance of basic research should be emphasised, since that research forms the foundations for the other levels in the model. Secondly, the move from Level 1 to 2 is often influenced by idiosyncratic historical factors within each discipline, yet the broad cultural context is crucial, and many disciplines seem to experience a 'takeoff' when issues of sustainability become widely debated. Opportunities for communication between disciplines are probably important here. However, fields - like archaeology - where the role of the natural environment in Level 1 research is contested may be much slower in this respect. A third conclusion is that, while Level 5 type interventions are ultimately crucial, disciplines such as archaeology need to consider further what such interventions might comprise for their particular areas of expertise and public interest.

Different disciplines bring different strengths and expertise to the model proposed here, and a truly sustainable future will be best supported by a diversity of approaches and the synergies between them. At the same time, academic disciplines form the primary organisational units within which research and outreach is conducted. Although the boundaries between disciplines are currently changing, due to both increasing specialisation within disciplines and integration between different fields (Pohl et al. 2008), the existing disciplines are a realistic startline for building sustainability science.

\section{ACKNOWLEDGEMENTS}

This research was supported by a grant-in-aid for Scientific Research on Innovative Areas, MEXT, Japan for project No. 21101005 'Pan-Pacific Environmental Changes and Civilizations' and by the Social Sciences and Humanities Research Council of Canada for the Baikal-Hokkaido Archaeology Project. 


\section{References}

Adger W. N., Barnett J., Chapin F. S. and Ellemor H. 2011. This must be the place: Underrepresentation of identity and meaning in climate change decision-making. Global Environmental Politics 11: 1-25.

Alaimo S. 2012. Sustainable this, sustainable that: New materialisms, posthumanism, and unknown futures. Publications of the Modern Language Association of America (PMLA) 127(3): 558-564.

Balée W., Erickson C. L. (eds.) 2006. Time and Complexity in Historical Ecology: Studies in the Neotropical Lowlands. Columbia University Press. New York.

Berkes F., Folke C. (eds.) 1998. Linking Social and Ecological Systems: Management Practices and Social Mechanisms for Building Resilience. Cambridge University Press. Cambridge.

Bohm D. 1996. On Dialog. Routledge. New York.

Bruun D. 1918. The Icelandic colonization of Greenland and the finding of Vineland. Meddelelser om Grønland $57(3)$.

Buell L., Heise U. K. and Thornber K. 2011. Literature and the environment. Annual Review of Environment and Resources 36: 417-440.

Butzer K. W. 2012. Collapse, environment, and society. Proceedings of the National Academy of Sciences USA 109(10): 3632-3639.

Chapin III F. S., Kofinas G. P. and Folke C. (eds.) 2009. Principles of Ecosystem Stewardship: Resilience-based Natural Resource Management in a Changing World. Springer. New York.

Chapin F. S. III, Pickett S. T. A., Power M. E., Jackson R. B., Carter D. M. and Duke C. 2011. Earth stewardship: a strategy for social-ecological transformation to reverse planetary degradation. Journal of Environmental Studies and Sciences 1: 44-53.

Childe V. G. 1928. The Most Ancient East: The Oriental Prelude to European Prehistory. Kegan Paul. London.

Clare L., Weninger B. 2010. Social and biophysical vulnerability of prehistoric societies to rapid climate change. Documenta Praehistorica 37: 283-292.

Clark W. C., Dickson N. M. 2003. Sustainability science: the emerging research paradigm. Proceedings of the $\mathrm{Na}$ tional Academy of Sciences USA 100(14): 8059-8061.
Cooper J., Sheets P. (eds.) 2012. Surviving Sudden Environmental Change: Answers from Archaeology. University Press of Colorado. Boulder.

Costanza R., Graumlich L. and Steffen W. (eds.) 2007. Sustainability or Collapse: An Integrated History and Future of People on Earth. MIT Press. Cambridge MA.

Crumley C. L. (ed.) 2001. New Directions in Anthropology and Environment: Intersections. AltaMira. Walnut Creek.

Crumley C. L. 2013. Historical ecology in archaeology. In C. Smith (ed.), Encyclopedia of Global Archaeology. Springer. New York. DOI 10.1007/978-1-4419-0465-2.

Crumley C. L., Marquardt W. H. (eds.) 1987. Regional Dynamics: Burgundian Landscapes in Historical Perspective. Academic Press. San Diego.

Dunning N. P., Beach T. P. and Luzzadder-Beach S. 2012. Kax and kol: collapse and resilience in lowland Maya civilization. Proceedings of the National Academy of Sciences USA 109(10): 3652-3657.

Endfield G. H. 2012. The resilience and adaptive capacity of social-environmental systems in colonial Mexico. Proceedings of the National Academy of Sciences USA 109(10): 3676-3681.

Fisher C. T., Hill J. B. and Feinman G. M. (eds.) 2009. The Archaeology of Environmental Change: Socionatural Legacies of Degradation and Resilience. University of Arizona Press. Tucson.

Folke C., Berkes F. and Colding J. 1998. Ecological practices and social mechanisms for building resilience and sustainability. In F. Berkes, C. Folke (eds.), Linking Social and Ecological Systems: Management Practices and Social Mechanisms for Building Resilience. Cambridge University Press. Cambridge: 414-436.

Folke C., Colding J. and Berkes F. 2003. Synthesis: building resilience and adaptive capacity in social-ecological systems. In F. Berkes, J. Colding and C. Folke (eds.), $\mathrm{Na}$ vigating Social-Ecological Systems: Building Resilience for Complexity and Change. Cambridge University Press. Cambridge: 352-387.

Folke C., Chapin F.S. III and Olsson P. 2009. Transformations in ecosystem stewardship. In F. S. Chapin III, G. P. Kofinas and C. Folke (eds.), Principles of Ecosystem Stewardship: Resilience-based Natural Resource Management in a Changing World. Springer. New York: 103125. 
Frank G., Murphy S. T., Kitching H. J., Garfield D. M. and McDarment N. 2008. The Tule River tribal history project: evaluating a California tribal government's collaboration with anthropology and occupational therapy to preserve Indigenous history and promote tribal goals. Human $\mathrm{Or}$ ganization 67: 430-442.

Frodeman R. 2011. Interdisciplinary research and academic sustainability: managing knowledge in an age of accountability. Environmental Conservation 38(2): 105112.

Gunderson L. H., Holling C. S. (eds.) 2002. Panarchy: Understanding Transformations in Human and Natural Systems. Island Press. Washington DC.

Habu J., Matsui A., Yamamoto N. and Kanno T. 2011. Shell midden archaeology in Japan. Quaternary International 239: 19-27.

Hardesty D. L. 2007. Perspectives on global-change archaeology. American Anthropologist 109(1): 1-7.

Hassan F. 2004. Ecology in archaeology: from cognition to action. In J. Bintliff (ed.), A Companion to Archaeology. Blackwell Companion to Archaeology. Blackwell. Oxford: 311-333.

Heise U. K. 2006. The hitchhiker's guide to ecocriticism. Publications of the Modern Language Association of America (PMLA) 121(2): 503-516.

Holling C. S. 1973. Resilience and stability of ecological systems. Annual Review of Ecology and Systematics 4: $1-24$.

Hudson M. J., Aoyama M., Hoover K. C. and Uchiyama J. 2012a. Prospects and challenges for an archaeology of global climate change. Wiley Interdisciplinary Reviews Climate Change 3: 313-328.

Hudson M. J., Aoyama M., Hoover K. C. 2012b. Navigating hunter-gatherer resilience: networks and insularity in the prehistory of the Ryukyu islands. In C. Damm and J. Saarikivi (eds.), Networks, Interaction and Emerging Identities in Fennoscandia and Beyond. Société Finno-Ougrienne. Helsinki: 49-66.

Kofinas G. P. 2009. Adaptive co-management in social-ecological governance. In F. S. Chapin III, G. P. Kofinas and C. Folke (eds.), Principles of Ecosystem Stewardship: Resilience-based Natural Resource Management in a Changing World. Springer. New York: 77-101.

Kristiansen K. 2002. The birth of ecological archaeology in Denmark. In A. Fischer and K. Kristiansen (eds.), The Neolithisation of Denmark: 150 Years of Debate. JR Collis. Sheffield: 9-31.
Lyman R. L., Cannon K. P. (eds.) 2004. Zooarchaeology and Conservation Biology. University of Utah Press. Salt Lake City.

Macinnes L., Wickham-Jones C. R. (eds.) 1992. All Natural Things: Archaeology and the Green Debate. Oxbow Monograph 21. Oxbow. Oxford.

McAnany P. A., Yoffee N. (eds.) 2010. Questioning Collapse: Human Resilience, Ecological Vulnerability, and the Aftermath of Empire. Cambridge University Press. Cambridge.

McGuire R. H. 2008. Archaeology as Political Action. California Series in Public Anthropology 17. University of California Press. Berkeley.

Menley T. 2012. 'The present obfuscation': Cowper's Task and the time of climate change. Publications of the Modern Language Association of America (PMLA) 127(3): 477-492.

Nisbet M. C., Hixon M. A., Moore K. D. and Nelson M. 2010. Four cultures: new synergies for engaging society on climate change. Frontiers in Ecology and the Environment 8: 329-331.

Oestigaard T. 2011. The nature of archaeology: beyond the linguistic turn. Norwegian Archaeological Review 44 (1): $68-71$.

Ostrom E. 2009. A general framework for analyzing sustainability of social-ecological systems. Science 325: 419422 .

Pickett S. T. A., Burch W. R. Jr. and Grove J. M. 1999. Interdisciplinary research: maintaining the constructive impulse in a culture of criticism. Ecosystems 2: 302-307.

Pohl C., von Kerkhoff L., Hirsch Hadorn C. and Bammer G. 2008. Core terms in transdisciplinary research. In C. Hirsch Hadorn, H. Hoffmann-Riem, S. Biber-Klemm, W. Grossenbacher-Mansuy, D. Joye, C. Pohl, U. Wiesmann and E. Zemp (eds.), Handbook of Transdisciplinary Research. Springer. Dordrecht: 427-432.

Redman C. L. 1999. Human Impact on Ancient Environments. University of Arizona Press. Tucson.

2005. Resilience theory in archaeology. American Anthropologist 107(1): 70-77.

Redman C. L., Nelson M. C. and Kinzig A. P. 2009. The resilience of socioecological landscapes: lessons from the Hohokam. In C. T. Fisher, J. B. Hill and G. M. Feinman (eds.), The Archaeology of Environmental Change: Socionatural Legacies of Degradation and Resilience. University of Arizona Press. Tucson: 15-39. 
Rosen A. M., Rivera-Collazo I. 2012. Climate change, adaptive cycles, and the persistence of foraging economies during the late Pleistocene/Holocene transition in the Levant. Proceedings of the National Academy of Sciences USA 109(10): 3640-3645.

Solli B. 2011. Some reflections on heritage and archaeology in the Anthropocene. Norwegian Archaeological Review 44(1): 40-54.

van der Leeuw S. 1998. The ARCHAEOMEDES Project: Understanding the Natural and Anthropogenic Causes of Land Degradation and Desertification in the Mediterranean Basin. Office of Publications of the European Union. Luxembourg.

Walker B., Salt D. 2006. Resilience Thinking: Sustaining Ecosystems and People in a Changing World. Island Press. Washington DC.
Xie J., Hu L. L., Tang J. J., Wu X., Li N., Yuan Y. G., Yang H. S., Zhang J. E., Luo S. M. and Chen X. 2011. Ecological mechanisms underlying the sustainability of the agricultural heritage rice-fish coculture system. Proceedings of the National Academy of Sciences USA 108(50): E1381E1387.

Yasuda Y. 1999. Kankyō kōkogaku ga chikyū to jinrui o sukū [Environmental archaeology saves the earth and humanity]. In Y. Yasuda (ed.), Hajimete Deau Nihon Kōkogaku [A First Introduction to Japanese Archaeology]. Yūhikaku, Tokyo: 3-42. (in Japanese).

Young O. R., King L. A. and Schroeder H. (eds.) 2008. Institutions and Environmental Change: Principal Findings, Applications, and Research Frontiers. MIT Press. Cambridge MA. 